\title{
Article \\ Factors Influencing the Formation of Salicylic Acid by Bipolar Membranes Electrodialysis
}

\author{
Juan Taumaturgo Medina-Collana ${ }^{1,+}+\mathbb{C}$, Jimmy Aurelio Rosales-Huamani ${ }^{2, *,+} \mathbb{C}$, Elmar Javier Franco-Gonzales ${ }^{2,+}+\mathbb{C}$ \\ and Jorge Alberto Montaño-Pisfil ${ }^{1,+}(\mathbb{D}$ \\ 1 Faculty of Chemical Engineering, National University of Callao, Juan Pablo II 306 Avenue, Bellavista, \\ Callao 07011, Peru; jtmedinac@unac.edu.pe (J.T.M.-C.); jamontanop@unac.edu.pe (J.A.M.-P.) \\ 2 Multidisciplinary Sensing, Universal Accessibility and Machine Learning Group, Faculty of Geological, \\ Mining and Metallurgical Engineering of the National University of Engineering, Lima 15333, Peru; \\ efrancog@uni.edu.pe \\ * Correspondence: jrosales@uni.edu.pe; Tel.: +51-1-381-5639 \\ + These authors contributed equally to this work.
}

Citation: Medina-Collana, J.T.; Rosales-Huamani, J.A.; FrancoGonzales, E.J.; Montaño-Pisfil, J.A. Factors Influencing the Formation of Salicylic Acid by Bipolar Membranes Electrodialysis. Membranes 2022, 12, 149. https://doi.org/10.3390/ membranes12020149

Academic Editor: Yan Zhao

Received: 28 December 2021

Accepted: 21 January 2022

Published: 26 January 2022

Publisher's Note: MDPI stays neutral with regard to jurisdictional claims in published maps and institutional affiliations.

Copyright: (C) 2022 by the authors. Licensee MDPI, Basel, Switzerland. This article is an open access article distributed under the terms and conditions of the Creative Commons Attribution (CC BY) license (https:// creativecommons.org/licenses/by/ $4.0 /)$.

\begin{abstract}
Salicylic acid is an intermediate product in the synthesis of dyes, medications and aspirin. An electrodialysis module has been constructed with commercial cationic, anionic and bipolar membranes for the conversion of sodium salicylate into salicylic acid. The effect of operating conditions such as applied electric potential, salt concentration, initial acid concentration and volumetric flow on bipolar membrane electrodialysis (BMED) yields were investigated using Taguchi analysis. The results obtained in $210 \mathrm{~min}$ of work show an average concentration of salicylic acid of $0.0185 \mathrm{M}$, an average electric current efficiency of $85.3 \%$, and a specific energy consumption of $2.24 \mathrm{kWh} / \mathrm{kg}$ of salicylic acid. It was concluded that the proposed bipolar membrane electrodialysis process is an efficient alternative to produce salicylic acid (SAH) from sodium salicylate (SANa) in an environmentally friendly manner. Furthermore, the production of sodium hydroxide was obtained as a by-product of the process carried out.
\end{abstract}

Keywords: bipolar membrane; electrodialysis; taguchi method; salicylic acid

\section{Introduction}

Salicylic acid or 2-hydroxybenzoic acid is widely distributed in the plant kingdom [1], and is most used for its analgesic, antipyretic and anti-inflammatory properties [2]. Salicylic acid (SAH) is an important raw material that has been used as an intermediate to synthesize drugs (such as aspirin) and cosmetics (used for the treatment of seborrheic dermatitis) [3].

Currently, the production of salicylic acid is based on Kolbe-Schmitt [4]. First, sodium phenolate is synthesized by the reaction between phenol and $\mathrm{NaOH}$. Second, the intermediate is transformed into sodium salicylate (SANa) by a carboxylation reaction under conditions of high pressure, high temperature and $\mathrm{CO}_{2}$ atmosphere. Third, salicylic acid is obtained by acidification using a huge amount of $\mathrm{H}_{2} \mathrm{SO}_{4}$. However, this process will not only consume a considerable amount of $\mathrm{H}_{2} \mathrm{SO}_{4}$, but will generate numerous $\mathrm{Na}_{2} \mathrm{SO}_{4}$ waste solutions with a concentration greater than $0.1 \% w / w$ [5]. Figure 1 shows the block diagram of the process for obtaining salicylic acid.



Figure 1. Production of salicylic acid by the Kolbe-Schmitt reaction. 
The production of salicylic acid is based on the Kolbe-Schmitt reaction by the following reaction, shown in Figure 2.

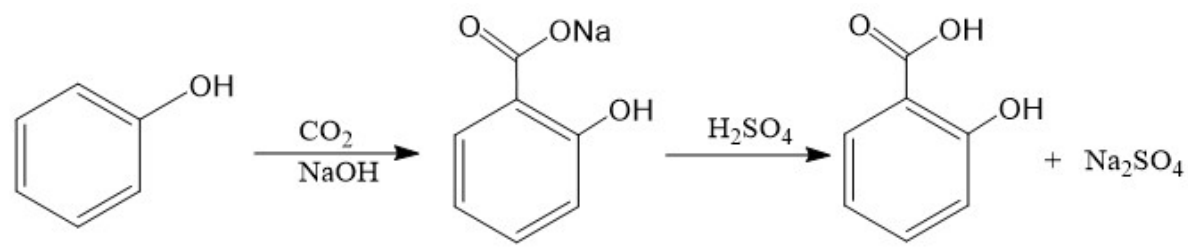

Figure 2. The Kolbe-Schmitt reaction.

As an advanced technical and environmentally friendly process, bipolar membrane electrodialysis (BMED) has been used as an alternative for the production of salicylic acid [5]. Electrodialysis technology has been applied to the treatment of high salt wastewater on an industrial scale since the 1950s [6]. Furthermore, the use of a bipolar membrane was introduced into the process in the 1970s, forming a new technology, electrodialysis with bipolar membranes (BMED), and expanding the application of this approach [7]. Among membrane technologies, electromembrane processes are promising technologies for the recovery of organic acids [8]. Electrodialysis (ED) is a separation process based on ion exchange membranes where positive ions are transported through a cation exchange membrane (CEM), and negative ions are transported through an anion exchange membrane (AEM) due to an applied electric field [9]. Electrodialysis (ED) allows the concentration and separation of cations / anions using cation exchange membranes (CEM) and anion exchange membranes (AEM). Furthermore, electrodialysis with bipolar membranes (BMED) is used to produce acids and bases from the corresponding salts [10,11].

Bipolar membrane electrodialysis technology (BMED) can be considered as a combination of a cation exchange membrane (CEM) and an anion exchange membrane (AEM); however, it has a different function than unipolar membranes [12]. BMED technology has been applied to the production of propionic acid [13], salicylic acid [14], gluconic acid [15] and other organic acids. The BMED dissociates water into protons and hydroxide, which move through the cation and anion layers of the bipolar membrane (FBM), respectively, and thus produce acidic and alkaline currents [16,17].

Independently, BMED has also been used effectively to produce or purify acids, as well as to adjust $\mathrm{pH}$ during fermentation or chemical synthesis in food and biochemical processing $[18,19]$. The BMED process has also been widely used for many years in the recovery of process water [20]. In [21], they used bipolar membranes for internal $\mathrm{pH}$ control in the electrodialysis of amino acids. Furthermore, [22] mentioned that the BMED process is a promising technology for the treatment of textile wastewater, as it produces acid and base from the salt content of the wastewater. In addition, it does not produce any waste stream that needs further treatment. Then, [23] observed that the maximum acid-base conductivity $(90,000 \mu \mathrm{S} / \mathrm{cm}$ in acid, $60,000 \mu \mathrm{S} / \mathrm{cm}$ in base) was reached with the BMED system using only the salt in the concentrate. Relating concentrations correspond to approximately $1.44 \%$ acids $(\mathrm{HCl})$ and $2 \%$ bases $(\mathrm{NaOH})$. Independently, [24] suggested an economic value of BMED for desalination of high salinity textile wastewater.

When an electric field is applied to the BMED cell, the following cathodic and anodic reactions take place at the related electrodes, [25] as shown in Equations (1) and (2).

$$
\begin{array}{cc}
\text { cathodic reaction: } & 2 \mathrm{H}_{2} \mathrm{O}+2 \mathrm{e}^{-} \rightarrow 2 \mathrm{OH}^{-}+\mathrm{H}_{2} \\
\text { anodic reaction: } & 2 \mathrm{H}_{2} \mathrm{O}-2 \mathrm{e}^{-} \rightarrow 4 \mathrm{H}^{+}+\mathrm{O}_{2}
\end{array}
$$

The water molecules that diffuse in the bipolar membrane are divided into ions $\mathrm{H}^{+}$ and $\mathrm{OH}^{-}$at the bipolar membrane interface both by the applied electric field and by the catalytic effect of the bipolar junction [26] as shown in Equation (3).

$$
\text { bipolar membrane: } \quad \mathrm{H}_{2} \mathrm{O} \rightarrow \mathrm{OH}^{-}+\mathrm{H}^{+}
$$


The $\mathrm{H}^{+}$ions pass through the cation exchange layer of the BPM towards the cathode side, while the $\mathrm{OH}^{-}$ions pass through the anion exchange layer towards the anode side.

The salts in the feed stream ionize in aqueous medium as shown in Equation (4). The cation and anion exchange membranes change the direction of the ions to the appropriate compartments under the effect of the electric field.

$$
\mathrm{C}_{7} \mathrm{H}_{5} \mathrm{O}_{3} \mathrm{Na} \rightarrow \mathrm{C}_{7} \mathrm{H}_{5} \mathrm{O}_{3}^{-}+\mathrm{Na}^{+}
$$

The $\mathrm{C}_{7} \mathrm{H}_{5} \mathrm{O}_{3}^{-}\left(\mathrm{SA}^{-}\right)$ions released migrate through the AEM and combine with the $\mathrm{H}^{+}$ions produced by the dissociation of water from the bipolar membrane to form pure salicylic acid (acid compartment), as shown in Equation (5).

$$
\mathrm{C}_{7} \mathrm{H}_{5} \mathrm{O}_{3}^{-}+\mathrm{H}^{+} \rightarrow \mathrm{C}_{7} \mathrm{H}_{5} \mathrm{O}_{3} \mathrm{H}
$$

Meanwhile, the released $\mathrm{Na}^{+}$ions migrate through the CEM and combine with the $\mathrm{OH}^{-}$ions produced by the dissociation of water to form pure sodium hydroxide (base compartment) [8], as shown in Equation (6).

$$
\mathrm{Na}^{+}+\mathrm{OH}^{-} \rightarrow \mathrm{NaOH}
$$

As an environmentally friendly and technical advanced process, bipolar membrane electrodialysis (BMED) has been used as an alternative for the production of salicylic acid [5].

The contribution of the work is the implementation, construction and evaluation of its own bipolar electrodialysis module. From there, the present study aimed to study the feasibility of the bipolar membrane electrodialysis process, and to evaluate the influence of operating factors during the bipolar electrodialysis process of the sodium salicylate salt in the formation of salicylic acid. Process parameters such as applied voltage, salt concentration, initial acid concentration, and flow affecting BMED have been evaluated. The result of this research shows the performance of the BMED process in the synthesis of salicylic acid and its influence on the operating variables of the equipment with respect to the acid concentration.

The present work is divided as follows: in Section 2 we mention the materials and methods to be used, in Section 3 we present the results and discussions carried out, and finally in Section 4 we discuss the conclusions obtained from this study.

\section{Materials and Methods}

\subsection{Materials}

The chemicals used in our research were analytically pure sodium salicylate salt, sodium hydroxide $(\mathrm{NaOH})$, sodium sulfate, and phenolphthalein. Deionized water with a concentration of 1 ppm was used for the analysis. The glass materials used were burettes to carry out the titration operation.

\subsection{Membranes}

The experiment involved the use of three types of membranes, cation exchange (CEM), anion exchange (AEM), and bipolar membrane (FBM) were supplied by the company (Fumatech Bwt GmbH, Bietigheim Bissingen, Germany) for the study. For a good functioning of the membrane, it is first immersed in distilled water for a period of $24 \mathrm{~h}$ and then in an aqueous solution of $\mathrm{NaCl} 0.25 \mathrm{~N}$ for the other $24 \mathrm{~h}$; the characteristics are shown in Table 1. 
Table 1. Membrane characteristics.

\begin{tabular}{lccc}
\hline Types of Membranes & CEM & AEM & FBM $[27,28]$ \\
\hline Electric resistance $\left(\Omega \mathrm{cm}^{2}\right)$. & $2.50-3.50$ & $2.50-3.50$ & $<3$ \\
Exchange capacity $(\mathrm{meq} / \mathrm{g})$ & $1.50-1.80$ & $1.40-1.70$ & \\
Thickness $(\mathrm{mm})$ & $0.17-0.19$ & $0.16-0.18$ & $0.13-0.16$ \\
\hline
\end{tabular}

For FBM, the membrane area resistance was measured as $\mathrm{Cl}^{-}$and $\mathrm{Na}^{+}$in $0.5 \mathrm{M} \mathrm{NaCl}$ solution and $0.25 \mathrm{M} \mathrm{Na}_{2} \mathrm{SO}_{4}$ electrode rinse solution at $25^{\circ} \mathrm{C}$, respectively [28].

\subsection{Chemical Analysis}

The changes in the concentration of salicylic acid and sodium hydroxide were determined by acid-base titration with a calibrated solution of $0.01 \mathrm{~N} \mathrm{NaOH}$ and $0.01 \mathrm{~N} \mathrm{HCl}$ using phenolphthalein as an indicator. The salicylic acid concentration was calculated by Equation (7) [14].

$$
\mathrm{C}_{\mathrm{AS}}=\frac{\mathrm{C}_{\mathrm{NaOH}} \mathrm{V}_{\mathrm{NaOH}}}{\mathrm{V}_{\mathrm{AS}}}
$$

$\mathrm{C}_{\mathrm{NaOH}}(\mathrm{mol} / \mathrm{L})$ : concentration of the calibrated $\mathrm{NaOH}$ solution.

$\mathrm{V}_{\mathrm{NaOH}}(\mathrm{L})$ : volume of the $\mathrm{NaOH}$.

$\mathrm{V}_{\mathrm{AS}}$ (L): volume of acid used for titration.

$\mathrm{C}_{\mathrm{AS}}$ : obtained concentration of salicylic acid.

\subsection{Membrane Configuration}

The BMED technology has been developed as a sustainable approach to split an aqueous saline stream into its corresponding acid and base without any use of chemicals [7]. BMED is configured with a series of ion exchange membranes, including anion exchange membranes (AEM), cation exchange membranes (CEM), and bipolar membranes (FBM) between a pair of electrodes [29]. This is shown in Figure 3.

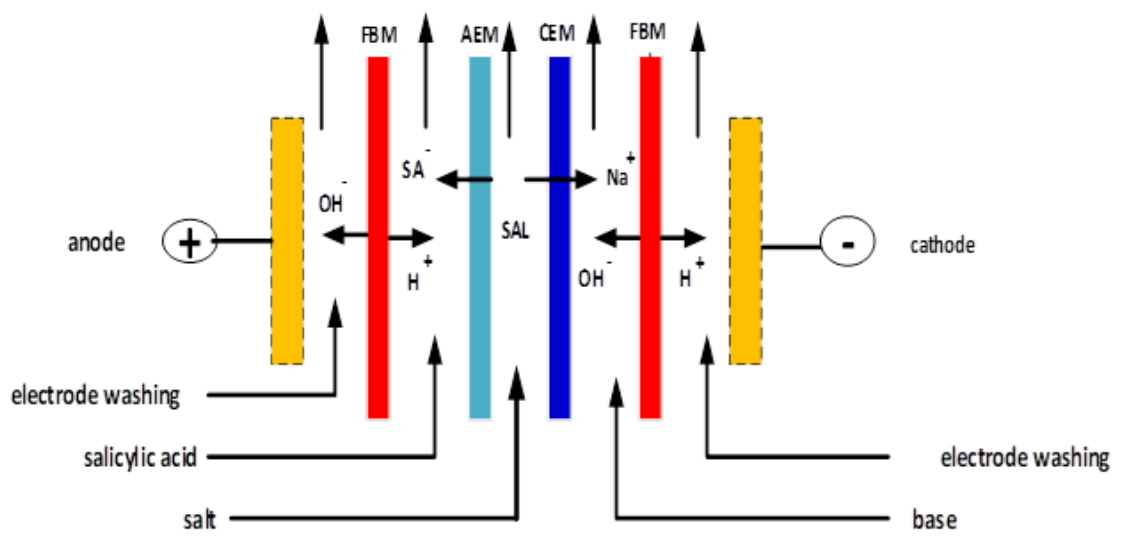

Figure 3. Schematic diagram of an BMED stack.

The transport of water by osmosis in the BMED compartments is not within the scope of this work. However, ion exchange membranes in electrodialysis should possess high perm selectivity and conductivity, low resistance, and high mechanical, dimensional, and chemical stability $[9,30,31]$.

\subsection{Electrodialysis Cell with Bipolar Membrane}

The bipolar membrane electrodialysis cell is a filter press type as shown in Figure 4, with five compartments (acid, salt, base and washing of cathode electrodes and washing of anode electrodes). It was built with acrylic material on which four membranes are 
assembled with their respective mesh-shaped turbulence promoters, alternately fixed and secured with eight cross bars with nuts to prevent leakage, mixing or spilling of the liquid as shown in Figure 5.

Rubber gaskets were placed between each frame and membrane that allows a seal in order to maintain uniform flow distribution within the cells, with two acrylic plates at the ends of each, with three inlets and three outlets for the flow of solutions.

The external acrylic plates allow the system to be kept under pressure, providing stability and resistance to the set of cells. The the electrodes are inserted into two $1.5 \mathrm{~cm}$ thich acrylic frames, each with an inlet and an outlet through which the electrode wash solution enters.

In all compartments, solutions were circulated in a batch mode using pumps; changes in concentration were measured by sampling at time intervals.

A direct current generator supplied a constant current. The titanium electrode, both anode and cathode, has a working area of $100 \mathrm{~cm}^{2}$, and each membrane has an effective area of $90 \mathrm{~cm}^{2}$ (total effective membrane area of $360 \mathrm{~cm}^{2}$ ). The experiments were carried out at a room temperature of $28^{\circ} \mathrm{C}$. As electrode washing solution, $2 \mathrm{~L}$ of $0.25 \mathrm{M}$ sodium sulfate was used, the initial concentration of sodium hydroxide in each experiment being $0.01 \mathrm{~N}$.

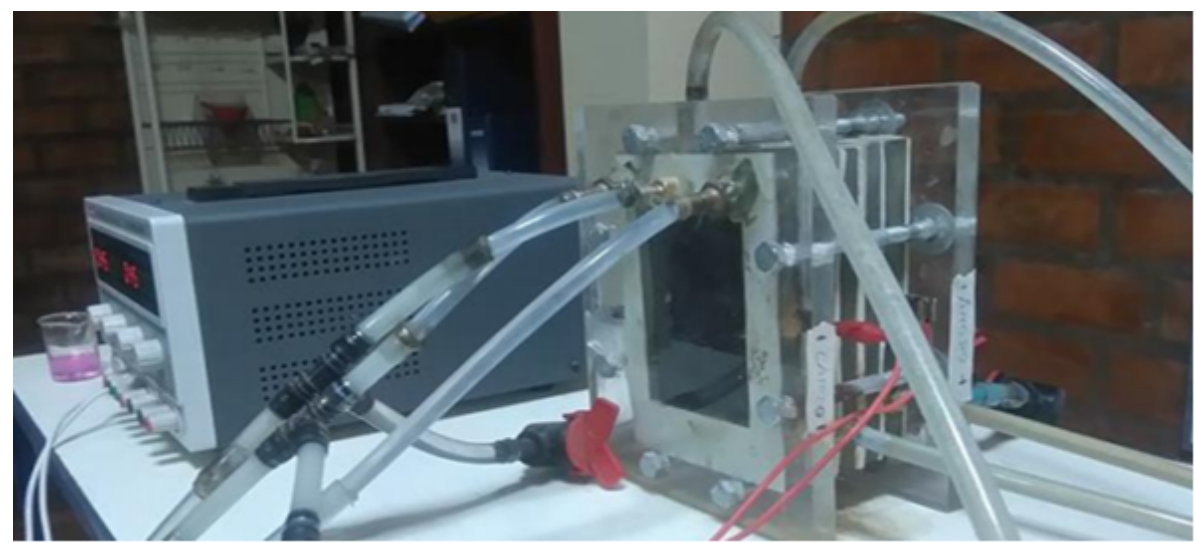

Figure 4. Filter press type.



Figure 5. Electrodialysis cell with bipolar membrane.

\subsection{Calculation of Current Efficiency and Energy Consumption}

The performance of BMED for salicylic acid synthesis was evaluated in terms of energy consumption $(\mathrm{E})$, and current efficiency $(\eta)$. 
The current efficiency $(\eta)$ is important for the characterization of the bipolar electrodialysis process. It was calculated by Equation (8) [32].

$$
\eta=\frac{z\left(C_{t}-C_{0}\right) V F}{N I t} \times 100 \%
$$

$C_{t}$ and $C_{0}(\mathrm{~mol} / \mathrm{L})$ : are the concentrations of salicylic acid at $t$ and zero time respectively. $V(L)$ : is the initial volume of the acid cycle.

$F$ : is the Faraday constant $\left(96,485 \mathrm{Cmol}^{-1}\right)$.

$t:$ (min) is the test time.

$I(A)$ : is the current applied; where $z$ is the ion's absolute valence $(z=1)$.

$N$ : is the number of repeating units $(N=1)$.

The energy consumption $\mathrm{E}(\mathrm{kWh} / \mathrm{kg})$ was calculated by Equation (9) [33].

$$
E\left(\frac{k W h}{k g}\right)=\frac{\int_{0}^{t} U I d t}{\left(C_{t}-C_{0}\right) V M}
$$

$U$ : is the voltage drop across the BMED stack $(V)$.

$I$ : is the current $(A)$.

$t:$ (min) is the test time.

$M$ : is the molecular weight of salicylic acid 138,122 (g/mol).

It is important to note that organic solutions are poor electrical conductors and can cause significant drops in electrical potential in BMED cells, causing higher energy consumption in said cell.

However, a limitation is that the products to be treated by BMED must have a high mineral content to allow good electrical conductivity. This is in order to decrease the overall resistance of the electrodialysis cell [34].

\subsection{Experimental Design Based on Taguchi Method}

The Taguchi method was used to design the experiments. The Taguchi method applies fractional factorial experimental designs, called orthogonal arrays, to reduce the number of experiments. The selection of a suitable orthogonal array depends on the number of control factors and their levels. The factors and their levels are presented in Table 2.

In this work, the effect of four important factors, including electric potential, initial concentration of the salicylic acid, the concentration of the salt, and the volumetric flow of recirculation of the solutions and each factor was studied at three levels on the concentration of salicylic acid. The design of the experiment using the Taguchi method provides a simple, efficient, and systematic approach to determine the optimum conditions [35]. With the selection of the $L_{9}\left(3^{4}\right)$ orthogonal array, the number of experiments required can be reduced to nine, which should be conducted in order to study the main effects and interactions, whereas full factorial experimentation would require $3^{4}=81$ experiments.

Table 2. Parameters and their values corresponding to their levels studie in experiments.

\begin{tabular}{ccccccc}
\hline \multirow{2}{*}{$\mathbf{N}^{\circ}$} & \multirow{2}{*}{ Factors } & Notation & Unit & \multicolumn{3}{c}{ Levels } \\
\cline { 5 - 7 } & & & Low & Medium & High \\
\hline 1 & Voltage supplied & $X_{1}$ & $\mathrm{~V}$ & 5 & 10 & 15 \\
2 & Salt concentration & $X_{2}$ & $\mathrm{~g} / \mathrm{L}$ & 20 & 25 & 30 \\
3 & Initial concentration & $X_{3}$ & $\mathrm{M}$ & 0.006 & 0.010 & 0.012 \\
& of salicylic acid & & & & & \\
4 & Volumetric flow & $X_{4}$ & $\mathrm{~mL} / \mathrm{min}$ & 400 & 700 & 1000 \\
\hline
\end{tabular}

For the membrane division voltage at $100 \mathrm{~mA} / \mathrm{cm}^{2}$ is less than $1.2 \mathrm{~V}$, in $0.5 \mathrm{M} \mathrm{NaCl}$ solution and $0.25 \mathrm{M} \mathrm{Na}_{2} \mathrm{SO}_{4}$ electrode rinse solution at $25^{\circ} \mathrm{C}$ [28]. In [7] mentioned that 
the maximum estimated voltage is $16 \mathrm{~V}$, taking into account the possible losses. Then we chose an interval of 5 to $15 \mathrm{~V}$ to carry out our experiments.

The other parameters have been chosen by conditions of the experiment, the electric potential being the most influential factor in the process to be carried out.

BMED experiments were performed using aqueous sodium salicylate solutions. The set of factor levels to be tested, the experimental parameters and their levels are given in Table 3.

Table 3. Taguchi $L_{9}\left(3^{4}\right)$.

\begin{tabular}{ccccc}
\hline \multirow{2}{*}{ Run } & \multicolumn{4}{c}{ Operating Parameters } \\
\cline { 2 - 5 } & $\boldsymbol{X}_{\mathbf{1}}$ & $\boldsymbol{X}_{\mathbf{2}}$ & $\boldsymbol{X}_{\mathbf{3}}$ & $\boldsymbol{X}_{\mathbf{4}}$ \\
\hline 1 & 5 & 20 & 0.006 & 400 \\
2 & 5 & 25 & 0.010 & 700 \\
3 & 5 & 30 & 0.012 & 1000 \\
4 & 10 & 20 & 0.010 & 1000 \\
5 & 10 & 25 & 0.012 & 400 \\
6 & 10 & 30 & 0.006 & 700 \\
7 & 15 & 20 & 0.012 & 700 \\
8 & 15 & 25 & 0.006 & 1000 \\
9 & 15 & 30 & 0.010 & 400 \\
\hline
\end{tabular}

\section{Results and Discussion}

The effects or influence of the operating parameters, that is, electric potential, initial concentration of salicylic acid, concentration of salt and recirculation flow of solutions with the Taguchi method are shown in Table 4.

Table 4. Response table.

\begin{tabular}{ccccccccc}
\hline & \multicolumn{3}{c}{ Operating Parameters } & \multicolumn{5}{c}{ Responses } \\
\cline { 2 - 9 } Run & $\boldsymbol{X}_{\mathbf{1}}$ & $\boldsymbol{X}_{\mathbf{2}}$ & $\boldsymbol{X}_{\mathbf{3}}$ & $\boldsymbol{X}_{\mathbf{4}}$ & $\begin{array}{c}\text { Salicylic Acid } \\
\text { Concentration } \\
\mathbf{( M )}\end{array}$ & $\begin{array}{c}\text { Salicylic Acid } \\
\text { Concentration } \\
\mathbf{( g / L )}\end{array}$ & $\begin{array}{c}\text { Electrical } \\
\text { Efficiency \% }(\eta)\end{array}$ & $\begin{array}{c}\text { Energy } \\
\text { Consumption } \\
(\mathbf{E} \mathbf{k W h} / \mathbf{k g})\end{array}$ \\
\hline 1 & 5 & 20 & 0.006 & 400 & 0.0087 & 1.2016 & 82.70 & 1.173 \\
\hline 2 & 5 & 25 & 0.010 & 700 & 0.0122 & 1.6850 & 84.24 & 1.151 \\
\hline 3 & 5 & 30 & 0.012 & 1000 & 0.0140 & 1.9330 & 76.58 & 1.267 \\
\hline 4 & 10 & 20 & 0.010 & 1000 & 0.0184 & 2.5410 & 85.73 & 2.111 \\
\hline 5 & 10 & 25 & 0.012 & 400 & 0.0207 & 2.8590 & 74.03 & 2.767 \\
\hline 6 & 10 & 30 & 0.006 & 700 & 0.0148 & 2.0440 & 96.28 & 2.015 \\
\hline 7 & 15 & 20 & 0.012 & 700 & 0.0293 & 4.0460 & 93.96 & 3.180 \\
\hline 8 & 15 & 25 & 0.006 & 1000 & 0.0202 & 2.7990 & 87.27 & 3.212 \\
\hline 9 & 15 & 30 & 0.010 & 400 & 0.0275 & 3.7980 & 87.25 & 3.330 \\
\hline
\end{tabular}

\subsection{Taguchi Analysis}

The Taguchi method produces the mean of means results, as indicated in Figures 6-8, respectively.

Main effects plots are presented for data averages of: salicylic acid concentration, Electric current efficiency, specific energy consumption caused by electric potential $\left(X_{1}\right)$, salt concentration $\left(X_{2}\right)$, initial acid concentration $\left(X_{3}\right)$ and flow $\left(X_{4}\right)$. 


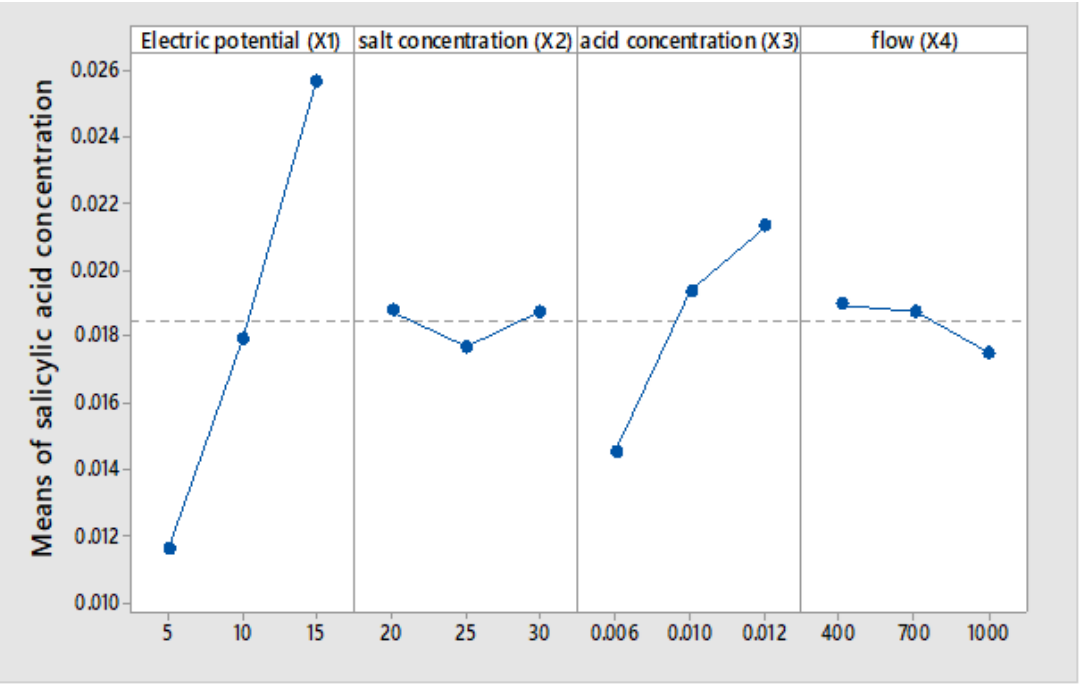

Figure 6. Main Effect Plot for Means of salicylic acid concentration.

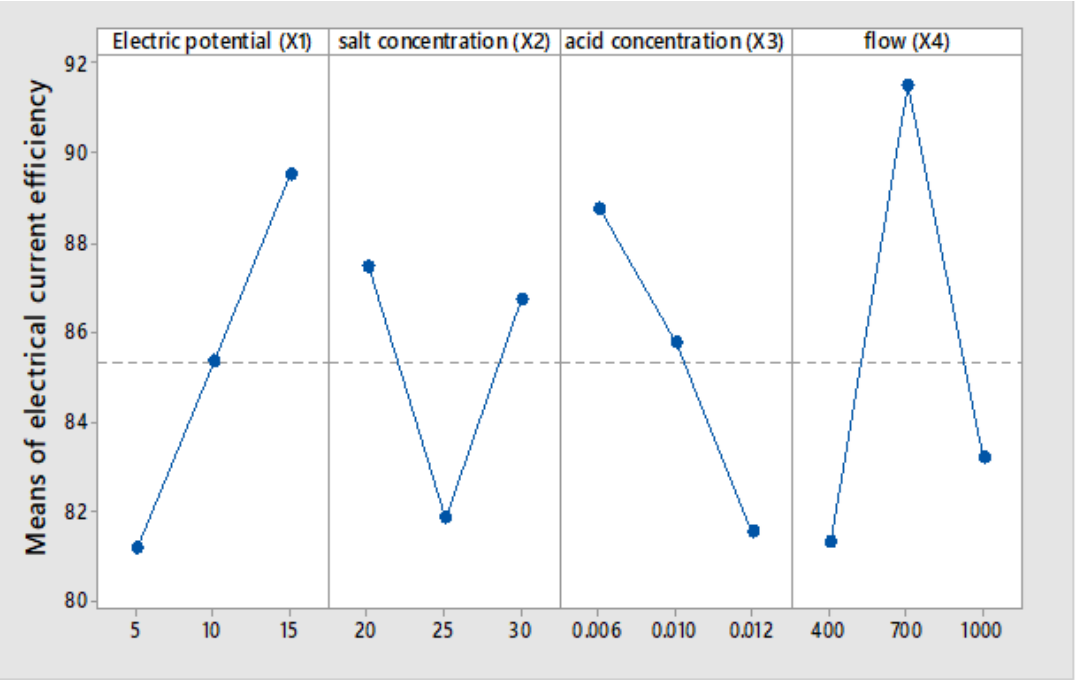

Figure 7. Main Effect Plot for Means of electrical current efficiency.

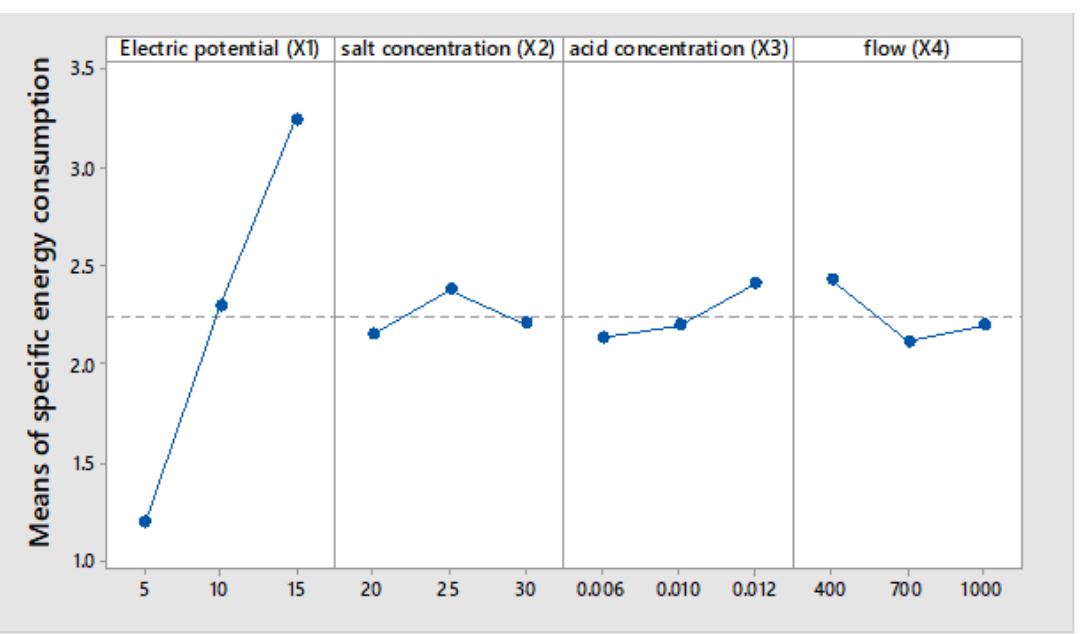

Figure 8. Main Effect Plot for Means of specific energy consumption. 


\subsection{Effects of Operating Conditions on the Response Parameters}

3.2.1. Effect of Applied Voltage $\left(X_{1}\right)$

Three electrical potentials: 5, 10 and $15 \mathrm{~V}$, were applied to the BMED cell to investigate the effect of voltage in the processing of salicylic acid. The results presented in Figure 6 show that an increase in applied voltage leads to a higher rate of acid production; the concentration of salicylic acid has a linear relationship of increase with the potential applied to the electrodialysis cell, and the average at 5 volts reaches a concentration of $0.0536 \mathrm{~N}$ and at 15 volts of $0.0256 \mathrm{~N}$.

Voltage is the driving force of BMED. Increasing the voltage obviously improves ion transport across membranes and increases the rate of dissociation of water in the bipolar membrane [36]. However, energy consumption must be taken into account on a commercial scale. It should be noted that increasing the voltage to a limit value can burn the membranes and lead to the electrolysis of the solution, as well as high energy consumption [26].

The results presented in Figure 7 indicate that the average electric current efficiency is $85.3 \%$, and it is observed that with the increase in the electric potential, the efficiency increases linearly at 15 volts, and $90 \%$ electric efficiency is reached. The results presented in Figure 8 show that the energy consumed to produce one kilogram of salicylic acid increases linearly with the voltage applied to the electrodialysis cell. The average at 5 volts achieves an energy consumption of $1.197 \mathrm{kWh} / \mathrm{kg}$ of salicylic acid compared to $3.241 \mathrm{kWh} / \mathrm{kg}$. The reason is that, as the voltage drop increases, a greater part of the energy is consumed to overcome the electrical resistance [25].

\subsubsection{Effect of Sodium Salicylate Concentration on the Production of Salicylic Acid $\left(X_{2}\right)$}

The effect of the concentration of the sodium salicylate salt at concentrations of 20, 25 and $30 \mathrm{~g} / \mathrm{L}$ on the production of salicylic acid was investigated. In Figure 6 it is observed that the concentration of the acid produced does not have significant changes with the increase in the concentration of sodium salicylate.

From Figure 7, it is observed that the electric current efficiency increases in the concentration range of 25 to $30 \mathrm{~g} / \mathrm{L}$ of the salt, and decreases in the range 20 to $25 \mathrm{~g} / \mathrm{L}$. The increase in current efficiency can be explained by the increase in salt concentration, which prevents the electrolysis of water on the surface of the membrane [37]. When the feed concentration exceeds $20 \mathrm{~g} / \mathrm{L}$, it is possible a part of the electrical energy is used to produce heat instead of ion migration, so that the current efficiency decreases.

From Figure 8 it is observed that when the salt concentration is at the low and high levels, the energy consumption is below the average that indicates $2.2 \mathrm{kWh} / \mathrm{kg}$ of salicylic acid. Regardless of other working conditions in [38] carried out in experiments with sodium salicylate solutions (SANa) by the cation exchange membrane process, they produced salicylic acid with a current efficiency close to $90 \%$ and an energy consumption of around $10 \mathrm{kWh} / \mathrm{kg}$ SAH produced.

\subsubsection{Effect of the Initial Concentration of Salicylic Acid $\left(X_{3}\right)$}

The effect of the initial concentration of aqueous solutions of salicylic acid with concentrations of $0.006 \mathrm{M}, 0.01 \mathrm{M}$ and $0.012 \mathrm{M}$ on the production of salicylic acid was investigated. In Figure 6 it is observed that the concentration of the acid produced increases significantly in the concentration range of $0.01-0.012 \mathrm{~mol} / \mathrm{L}$; this explains that, for very low concentrations, the aqueous solution of salicylic acid has low electrical conductivity.

The results presented in Figure 7 show that the efficiency of the electric current decreases as the initial concentrations of salicylic acid increase. At a concentration of $0.006 \mathrm{M}$, an average electric current efficiency of $89 \%$ is observed. At a concentration of $0.012 \mathrm{~N}$, an average electric current efficiency of $81.52 \%$ is obtained. The energy consumption seems to be independent of the initial concentration of salicylic acid. However the results presented in Figure 8 show that the energy consumption at a concentration of $0.006 \mathrm{~N}$ is $2.1 \mathrm{kWh} / \mathrm{kg}$ and at a concentration of $0.012 \mathrm{~N}$ is $2.5 \mathrm{kWh} / \mathrm{kg}$ of acid, respectively. 


\subsubsection{Effect of Flow $\left(X_{4}\right)$}

The flow rates with which the electrolytes were circulated on the BMED module varied between 400, 700 and $1000 \mathrm{~mL} / \mathrm{min}$. The results presented in Figure 6 show that it does not present very significant changes in the three levels of flow experimentation; however, it is observed that the lower the flow, the higher the concentration of salicylic acid is reached. Increasing the flow rate decreases the residence time in the electrodialysis cell, and increasing the residence time is equivalent to improving the effective contact area of the membrane with the solutions.

Figure 7 shows that increasing the flow rate from $400 \mathrm{~mL} / \mathrm{min}$ to $700 \mathrm{~mL} / \mathrm{min}$ in the BMED cell results in an increase in the efficiency of the electric current by $10 \%$. Increasing the flow rate may increase the linear velocity, which reduces the electrical resistance of the BMED cell. When the flow rate is increased from 700 to $1000 \mathrm{~mL} / \mathrm{min}$, the current efficiency decreases by $8 \%$ due to the reduction of the residence time.

From Figure 8 it is observed that the energy consumption does not present significant changes with the change of flow, however, a lower energy consumption of $2 \mathrm{kWh} / \mathrm{kg}$ of salicylic acid is observed at $700 \mathrm{~mL} / \mathrm{min}$.

\subsection{Anova Results}

The purpose of analysis of variance (ANOVA) is to investigate which process parameter significantly affected the response. The ANOVA evaluation also allows a greater understanding of whether the obtained findings are acceptable and whether the experiments are carried out under controlled conditions [39].

The analysis of variance of the salicylic acid concentration, electric current efficiency, specific energy consumption and the percentage contribution of each parameter is shown in Table 5.

According to these results, it is found that the electric potential applied to the BMED cell is the most significant factor affecting the concentration of salicylic acid, with a contribution of $78.93 \%$. It is observed that the most significant factor that contributes to the efficiency of the electric current is the volumetric flow at $42.41 \%$ and to a lesser degree the electric potential with $25.05 \%$. The factor that contributes to lower energy consumption is the electrical potential, which reached $94.64 \%$.

Table 5. ANOVA for acid concentration, electrical efficiency and energy consumption.

\begin{tabular}{lcccccc}
\hline Variables Responses & Factor & DOF & Sum of Squares & Contribution(\%) & SS Ajust & Mc ajus \\
\hline \multirow{5}{*}{ Concentration of Salicylic acid } & $X_{1}$ & 2 & $29.6 \times 10^{-5}$ & 78.93 & $0.3 \times 10^{-3}$ & $14.8 \times 10^{-5}$ \\
& $X_{2}$ & 2 & $0.2 \times 10^{-5}$ & 0.5 & $0.3 \times 10^{-3}$ & $0.1 \times 10^{-5}$ \\
& $X_{3}$ & 2 & $7.3 \times 10^{-5}$ & 19.43 & $0.7 \times 10^{-4}$ & $3.6 \times 10^{-5}$ \\
& $X_{4}$ & 2 & $0.4 \times 10^{-5}$ & 1.06 & $0.4 \times 10^{-5}$ & $0.2 \times 10^{-5}$ \\
\hline & Total & 8 & $37.5 \times 10^{-5}$ & 100 & & \\
\hline \multirow{5}{*}{ Electric current efficiency } & $X_{1}$ & 2 & 103.834 & 25.05 & 103.834 & 51.9170 \\
& $X_{2}$ & 2 & 55.712 & 13.44 & 55.712 & 27.8559 \\
& $X_{3}$ & 2 & 79.065 & 19.08 & 79.065 & 39.5325 \\
& $X_{4}$ & 2 & 175.736 & 42.41 & 175.736 & 87.8678 \\
\hline \multirow{5}{*}{ Specific energy consumption } & Total & 8 & 414.346 & 100 & & \\
& $X_{1}$ & 2 & 6.27729 & 94.64 & 6.27729 & 3.13864 \\
& $X_{2}$ & 2 & 0.08153 & 1.220 & 0.08153 & 0.04077 \\
& $X_{3}$ & 2 & 0.12070 & 1.810 & 0.12070 & 0.06035 \\
& $X_{4}$ & 2 & 0.15286 & 2.300 & 0.15286 & 0.07643 \\
\hline
\end{tabular}


The results presented in Table 6 show the delta values, which is the difference between the maximum and minimum values obtained for each factor, allowing the factors to be organized in order of significant influence regarding the response.

Regarding the concentration of the salicylic acid produced, the following are obtained: $X_{1}, X_{3}, X_{4}$ and $X_{2}$ in descending order; electric current efficiency $X_{4}, X_{1}, X_{3}$ and $X_{2}$; electric power consumption $X_{1}, X_{4}, X_{3}$ and $X_{2}$.

Table 6. Order of influence of response parameters.

\begin{tabular}{lccccc}
\hline \multirow{2}{*}{ Variables Responses } & Levels & \multicolumn{4}{c}{ Factors } \\
\cline { 3 - 6 } & & $\boldsymbol{X}_{\mathbf{1}}$ & $\boldsymbol{X}_{\mathbf{2}}$ & $\boldsymbol{X}_{\mathbf{3}}$ & $\boldsymbol{X}_{\mathbf{4}}$ \\
\hline \multirow{3}{*}{ Concentration of salicylic acid } & 2 & 0.01163 & 0.01880 & 0.01457 & 0.01897 \\
& 3 & 0.01797 & 0.01770 & 0.01937 & 0.01877 \\
& Delta & 0.01403 & 0.00110 & 0.00677 & 0.00143 \\
& Sort out & 1 & 4 & 2 & 3 \\
\hline \multirow{3}{*}{ Electric current efficiency } & 1 & 81.17 & 87.46 & 88.75 & 81.33 \\
& 2 & 85.35 & 81.85 & 85.74 & 91.49 \\
& 3 & 89.49 & 86.70 & 81.52 & 83.19 \\
\hline \multirow{3}{*}{ Specific energy consumption } & Delta & 8.32 & 5.62 & 7.23 & 10.17 \\
& Sort out & 2 & 4 & 3 & 1 \\
\hline & 1 & 1.197 & 2.155 & 2.133 & 2.423 \\
& 2 & 2.298 & 2.377 & 2.197 & 2.115 \\
& 3 & 3.241 & 2.204 & 2.405 & 2.197 \\
\hline & Delta & 2.044 & 0.222 & 0.271 & 0.308 \\
& Sort out & 1 & 4 & 3 & 2 \\
\hline
\end{tabular}

The results presented in Figures 9 and 10 show that the concentration of salicylic acid and sodium hydroxide varies linearly with the operating time of the electrodialysis cell, regardless of the applied voltage. An increase in the potential to the cell from 5 to $15 \mathrm{~V}$ leads to a higher concentration of acid and base; at approximately $0.30 \mathrm{~mol} / \mathrm{L}$ of salicylic acid and $0.29 \mathrm{~mol} / \mathrm{L}$ of sodium hydroxide occurs at a potential of 15 Volts.



Figure 9. Salicylic acid concentration in the acid compartment at various electric potentials as a function of time. 


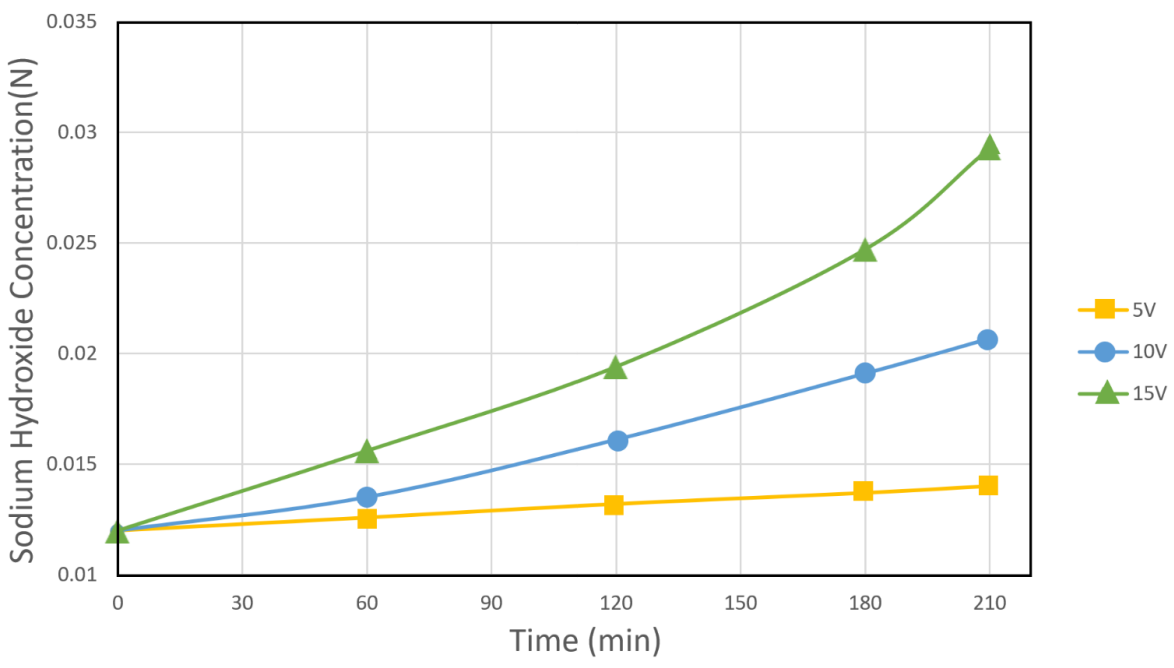

Figure 10. Sodium hydroxide concentration at various electric potential as a function of time.

These values are very similar to those reported in [5] working at different current densities such as: 30, 50 and $75 \mathrm{~mA} / \mathrm{cm}^{2}$ with an initial concentration of salicylic acid of $2 \mathrm{~g} / \mathrm{L}$. The following values were obtained as salicylic acid concentration: 3.4, 3.0 and $4.6 \mathrm{~g} / \mathrm{L}$ in an operating time of $30 \mathrm{~min}$ as indicated in Table 7.

Table 7. Comparative data for salicylic acid concentration and current density.

\begin{tabular}{ccccc}
\hline Experiment & $\begin{array}{c}\text { Electric } \\
\text { Potential (V) }\end{array}$ & $\begin{array}{c}\text { Salicylic Acid } \\
\text { Concentration (g/L) }\end{array}$ & $\begin{array}{c}\text { Density of Electric } \\
\text { Current (mA/cm }{ }^{2} \text { ) [5] }\end{array}$ & $\begin{array}{c}\text { Salicylic Acid } \\
\text { Concentration (g/L) [5] }\end{array}$ \\
\hline 1 & 5 & 1.606 & 30 & 3.4 \\
2 & 10 & 2.481 & 50 & 4.0 \\
3 & 15 & 3.547 & 75 & 4.6 \\
\hline
\end{tabular}

In [40], it was mentioned that the energy consumption of the BMED process for the production of gluconic acid increases almost linearly with the increase in current. The increasing trend of power consumption is consistent with Ohm's law. Being works with productions of different substances, there is a certain similarity in the experimental data obtained in [40] as shown in Table 8.

Table 8. Comparative data of Energy consumption (E).

\begin{tabular}{|c|c|c|c|c|}
\hline Experiment & $\begin{array}{c}\text { Electric } \\
\text { Potential (V) }\end{array}$ & $\begin{array}{c}\text { Energy Consumption } \\
(\mathbf{k W h} / \mathbf{k g})\end{array}$ & $\begin{array}{l}\text { Electric Current } \\
\text { Intensity (A) [40] }\end{array}$ & $\begin{array}{l}\text { Energy Consumption } \\
(\mathrm{kWh} / \mathrm{kg})[40]\end{array}$ \\
\hline 1 & 5 & 1.197 & 10 & 1.2 \\
\hline 2 & 10 & 2.297 & 20 & 2.1 \\
\hline 3 & 15 & 3.240 & 30 & 3.0 \\
\hline
\end{tabular}

As for the electric current efficiency values $(\eta)$, they are very similar to those reported in [38]. As shown in Table 9.

The research work developed is not within the scope of evaluating the production cost of salicylic acid. However, in [40] it was mentioned that the cost of the energy consumption increases linearly with the increase in current. The contribution to the total cost of the process increases from 13 to $73 \%$ when the current increases from 10 to $50 \mathrm{~A}$. Then in [41] indicated that the total investment is the sum of the cost of the battery and the cost of the peripheral equipment. 
Table 9. Comparative data of Electrical efficiency $(\eta)$.

\begin{tabular}{ccccc}
\hline Experiment & $\begin{array}{c}\text { Electric Potential } \\
(\mathbf{V})\end{array}$ & $\boldsymbol{\eta}$ & $\begin{array}{c}\text { Density of Electrical } \\
\text { Current }\left(\mathbf{m A} / \mathbf{c m}^{2}\right)[38]\end{array}$ & $\eta[38]$ \\
\hline 1 & 5 & 81.17 & 2.0 & 86.80 \\
2 & 10 & 85.34 & 5.0 & 89.41 \\
3 & 15 & 88.82 & 7.5 & 51.84 \\
\hline
\end{tabular}

\title{
4. Conclusions
}

A laboratory scale experimental setup was used to verify the viability of BMED to produce salicylic acid from sodium salicylate. An electrodialysis module has been constructed with commercial cationic, anionic and bipolar exchange membranes for the conversion of sodium salicylate to salicylic acid.

The effect of operating conditions, such as applied electrical potential, salt concentration, initial acid concentration, and volumetric flow on BMED yields was investigated. The performance of the module was quantified in terms of salicylic acid concentration, electric current efficiency and specific energy consumption $(\mathrm{kWh} / \mathrm{kg}$ of salicylic acid), as shown in the figures in Section 3.1.

Taguchi's methodology shows us that in Figure 6, the electric potential of the cell and the initial acid concentration are the most representative parameters of the salicylic acid production process. The results observed in Figures 7 and 8 indicate average electric current efficiencies of $85.3 \%$, and the specific energy consumption is $2.24 \mathrm{kWh} / \mathrm{kg}$ of salicylic acid, respectively.

The experimental results indicate that the four-compartment BMED process can be applied to prepare salicylic acid and sodium hydroxide, and will also achieve environmental benefits.

Author Contributions: Conceptualization, J.A.R.-H. and J.T.M.-C.; methodology, J.T.M.-C.; software, E.J.F.-G.; validation, J.A.M.-P.; formal analysis, J.A.M.-P.; investigation, J.A.R.-H.; writing-original draft preparation, E.J.F.-G.; writing—review and editing, J.A.R.-H.; visualization, J.T.M.-C. All authors have read and agreed to the published version of the manuscript.

Funding: This research received no external funding.

Institutional Review Board Statement: Not applicable.

Informed Consent Statement: Not applicable.

Data Availability Statement: Not applicable.

Conflicts of Interest: The authors declare that they have no conflicts of interest.

\author{
Abbreviations \\ The following abbreviations are used in this manuscript: \\ MDPI Multidisciplinary Digital Publishing Institute \\ DOAJ Directory of open access journals \\ TLA Three letter acronym \\ LD Linear dichroism
}

\section{References}

1. Boullard, O.; Leblanc, H.; Besson, B. Salicylic acid. Ullmann's Encycl. Ind. Chem. 2000, 106, 22432.

2. Madan, R.K.; Levitt, J. A review of toxicity from topical salicylic acid preparations. J. Am. Acad. Dermatol. 2014, 70, 788-792. [CrossRef] [PubMed]

3. Steele, K.; Shirodaria, P.; O’hare, M.; Merrett, J.; Irwin, W.; Simpson, D.; Pfister, H. Monochloroacetic acid and $60 \%$ salicylic acid as a treatment for simple plantar warts: Effectiveness and mode of action. Br. J. Dermatol. 1988, 118, 537-544. [CrossRef] [PubMed] 
4. Wiley, J. Kirk-Othmer Encyclopedia of Chemical Technology, Nickel and Nickel Alloys to Paint and Pigment Dispersing. 1995. Available online: https:/ / www.amazon.com/Kirk-Othmer-Encyclopedia-Chemical-Technology-Dispersing/dp/047152686X (accessed on 8 January 2022).

5. Alvarez, F.; Alvarez, R.; Coca, J.; Sandeaux, J.; Sandeaux, R.; Gavach, C. Salicylic acid production by electrodialysis with bipolar membranes. J. Membr. Sci. 1997, 123, 61-69. [CrossRef]

6. Caprarescu, S.; Corobea, M.C.; Purcar, V.; Spataru, C.I.; Ianchis, R.; Vasilievici, G.; Vuluga, Z. San copolymer membranes with ion exchangers for $\mathrm{Cu}$ (II) removal from synthetic wastewater by electrodialysis. J. Environ. Sci. 2015, 35, 27-37. [CrossRef]

7. Ghyselbrecht, K.; Silva, A.; Van der Bruggen, B.; Boussu, K.; Meesschaert, B.; Pinoy, L. Desalination feasibility study of an industrial $\mathrm{NaCl}$ stream by bipolar membrane electrodialysis. J. Environ. Manag. 2014, 140, 69-75. [CrossRef]

8. Handojo, L.; Wardani, A.; Regina, D.; Bella, C.; Kresnowati, M.; Wenten, I. Electro-membrane processes for organic acid recovery. RSC Adv. 2019, 9, 7854-7869. [CrossRef]

9. Strathmann, H. Electrodialysis, a mature technology with a multitude of new applications. Desalination 2010, 264, 268-288. [CrossRef]

10. El Rayess, Y.; Mietton-Peuchot, M. Membrane technologies in wine industry: An overview. Crit. Rev. Food Sci. Nutr. 2016, 56, 2005-2020. [CrossRef]

11. Reig, M.; Casas, S.; Valderrama, C.; Gibert, O.; Cortina, J. Integration of monopolar and bipolar electrodialysis for valorization of seawater reverse osmosis desalination brines: Production of strong acid and base. Desalination 2016, 398, 87-97. [CrossRef]

12. Lei, C.; Li, Z.; Gao, Q.; Fu, R.; Wang, W.; Li, Q.; Liu, Z. Comparative study on the production of gluconic acid by electrodialysis and bipolar membrane electrodialysis: Effects of cell configurations. J. Membr. Sci. 2020, 608, 118192. [CrossRef]

13. Boyaval, P.; Seta, J.; Gavach, C. Concentrated propionic acid production by electrodialysis. Enzym. Microb. Technol. 1993, 15, 683-686. [CrossRef]

14. Liu, X.; Li, Q.; Jiang, C.; Lin, X.; Xu, T. Bipolar membrane electrodialysis in aqua-ethanol medium: Production of salicylic acid. J. Membr. Sci. 2015, 482, 76-82. [CrossRef]

15. Wang, Y.; Zhang, X.; Xu, T. Integration of conventional electrodialysis and electrodialysis with bipolar membranes for production of organic acids. J. Membr. Sci. 2010, 365, 294-301. [CrossRef]

16. Ran, J.; Wu, L.; He, Y.; Yang, Z.; Wang, Y.; Jiang, C.; Ge, L.; Bakangura, E.; Xu, T. Ion exchange membranes: New developments and applications. J. Membr. Sci. 2017, 522, 267-291. [CrossRef]

17. Sleutels, T.H.; Hamelers, H.V.; Rozendal, R.A.; Buisman, C.J. Ion transport resistance in microbial electrolysis cells with anion and cation exchange membranes. Int. J. Hydrogen Energy 2009, 34, 3612-3620. [CrossRef]

18. Rozoy, E.; Boudesocque, L.; Bazinet, L. Deacidification of cranberry juice by electrodialysis with bipolar membranes. J. Agric. Food Chem. 2015, 63, 642-651. [CrossRef]

19. Zhang, X.; Wang, X.; Wang, Y.; Li, C.; Feng, H.; Xu, T. Production of yellow iron oxide pigments by integration of the air oxidation process with bipolar membrane electrodialysis. Ind. Eng. Chem. Res. 2014, 53, 1580-1587. [CrossRef]

20. Sun, Y.; Wang, Y.; Peng, Z.; Liu, Y. Treatment of high salinity sulfanilic acid wastewater by bipolar membrane electrodialysis. Sep. Purif. Technol. 2022, 281, 119842. [CrossRef]

21. Readi, O.K.; Kuenen, H.; Zwijnenberg, H.J.; Nijmeijer, K. Novel membrane concept for internal pH control in electrodialysis of amino acids using a segmented bipolar membrane (sBPM). J. Membr. Sci. 2013, 443, 219-226. [CrossRef]

22. Yuzer, B.; Selcuk, H. Recovery of Biologically Treated Textile Wastewater by Ozonation and Subsequent Bipolar Membrane Electrodialysis Process. Membranes 2021, 11, 900. [CrossRef] [PubMed]

23. Gazigil, L.; Er, E.; Kestioğlu, O.E.; Yonar, T. Pilot-Scale Test Results of Electrodialysis Bipolar Membrane for Reverse-Osmosis Concentrate Recovery. Membranes 2022, 12, 83. [CrossRef]

24. Berkessa, Y.W.; Lang, Q.; Yan, B.; Kuang, S.; Mao, D.; Shu, L.; Zhang, Y. Anion exchange membrane organic fouling and mitigation in salt valorization process from high salinity textile wastewater by bipolar membrane electrodialysis. Desalination 2019, 465, 94-103. [CrossRef]

25. Noguchi, M.; Nakamura, Y.; Shoji, T.; Iizuka, A.; Yamasaki, A. Simultaneous removal and recovery of boron from waste water by multi-step bipolar membrane electrodialysis. J. Water Process Eng. 2018, 23, 299-305. [CrossRef]

26. Nikbakht, R.; Sadrzadeh, M.; Mohammadi, T. Effect of operating parameters on concentration of citric acid using electrodialysis J. Food Eng. 2007, 83, 596-604. [CrossRef]

27. Igliński, B.; Piechota, G.; Iwański, P. Modification of Citric Acid Technology Using Electrodialysis. Sustain. Chem. Eng. 2020, 2020, 62-71. [CrossRef]

28. Fuelcellstore. Available online: www.fuelcellstore.com/spec-sheets/fumasep-fbm-pk-technical-specifications.pdf (accessed on 3 October 2021).

29. Chen, X.; Chen, G.Q.; Wang, Q.; Xu, T.; Kentish, S.E. Transforming salty whey into cleaning chemicals using electrodialysis with bipolar membranes. Desalination 2020, 492, 114598. [CrossRef]

30. Warsinger, D.M.; Chakraborty, S.; Tow, E.W.; Plumlee, M.H.; Bellona, C.; Loutatidou, S.; Karimi, L.; Mikelonis, A.M.; Achilli, A.; Ghassemi, A.; et al. A review of polymeric membranes and processes for potable water reuse. Prog. Polym. Sci. 2018, 81, 209-237. [CrossRef]

31. Strathmann, H.; Grabowski, A.; Eigenberger, G. Ion-exchange membranes in the chemical process industry. Ind. Eng. Chem. Res. 2013, 52, 10364-10379. [CrossRef] 
32. Badruzzaman, M.; Oppenheimer, J.; Adham, S.; Kumar, M. Innovative beneficial reuse of reverse osmosis concentrate using bipolar membrane electrodialysis and electrochlorination processes. J. Membr. Sci. 2009, 326, 392-399. [CrossRef]

33. Tongwen, X.; Weihua, Y. Citric acid production by electrodialysis with bipolar membranes. Chem. Eng. Process. Process Intensif. 2002, 41, 519-524. [CrossRef]

34. Bazinet, L.; Lamarche, F.; Ippersiel, D. Bipolar-membrane electrodialysis: Applications of electrodialysis in the food industry. Trends Food Sci. Technol. 1998, 9, 107-113. [CrossRef]

35. Deniz, F. Optimization of methyl orange bioremoval by Prunus amygdalus L.(almond) shell waste: Taguchi methodology approach and biosorption system design. Desalin. Water Treat. 2013, 51, 7067-7073. [CrossRef]

36. Vermaas, D.A.; Wiegman, S.; Nagaki, T.; Smith, W.A. Ion transport mechanisms in bipolar membranes for (photo) electrochemical water splitting. Sustain. Energy Fuels 2018, 2, 2006-2015. [CrossRef]

37. Shen, J.; Hou, Z.; Gao, C. Using bipolar membrane electrodialysis to synthesize di-quaternary ammonium hydroxide and optimization design by response surface methodology. Chin. J. Chem. Eng. 2017, 25, 1176-1181. [CrossRef]

38. Kumar, M.; Tripathi, B.P.; Shahi, V.K. Electro-membrane process for in situ ion substitution and separation of salicylic acid from its sodium salt. Ind. Eng. Chem. Res. 2009, 48, 923-930. [CrossRef]

39. Razmi, B.; Ghasemi-Fasaei, R. Investigation of Taguchi optimization, equilibrium isotherms, and kinetic modeling for phosphorus adsorption onto natural zeolite of clinoptilolite type. Adsorpt. Sci. Technol. 2018, 36, 1470-1483. [CrossRef]

40. Wang, Y.; Wang, A.; Zhang, X.; Xu, T. Simulation of electrodialysis with bipolar membranes: Estimation of process performance and energy consumption. Ind. Eng. Chem. Res. 2011, 50, 13911-13921. [CrossRef]

41. Wang, Y.; Li, W.; Yan, H.; Xu, T. Removal of heat stable salts (HSS) from spent alkanolamine wastewater using electrodialysis. J. Ind. Eng. Chem. 2018, 57, 356-362. [CrossRef] 